A N N A L E S

UNIVER S T ATIS M A R A E C URIE-SKŁO D W S K A

LUBLIN - POLONIA

VOL. XXXII, 1

SECTIO J

2019

*Ternopil Volodymyr Hnatiuk National Pedagogical University

**Kremenets Taras Shevchenko Regional Humanitarian Pedagogical Academy

\title{
OKSANA ROMANYSHYNA*
}

ORCID ID: https://orcid.org/0000-0002-2887-5023

oksroman@gmail.com

\section{ANTONINA GURA**}

ORCID ID: https://orcid.org/0000-0002-8004-4606

toniagura@gmail.com

\section{Using Google Services in Training of Future Teachers of Natural Specialties}

Korzystanie z usług Google w kształceniu przyszłych nauczycieli przedmiotów przyrodniczych

\section{STRESZCZENIE}

Dzięki nowoczesnym osiągnięciom informatycznym w działalności naukowej możliwy jest coraz szerszy dostęp do danych z wielu repozytoriów informacji. Celem artykułu jest określenie pedagogicznych możliwości korzystania z usług Google w kształceniu przyszłych nauczycieli przedmiotów przyrodniczych. W pracy badawczej podkreślono wyniki oceny rzeczywistego stanu aktywności edukacyjnej nauczycieli i uczniów z wykorzystaniem nowoczesnych technologii informacyjno-komunikacyjnych (ICT). W pracy przeanalizowano cele nauczania i szeroko stosowane usługi, które umożliwiają aktywne wprowadzanie ICT do procesu prowadzenia wykładów i zajęć praktycznych, przygotowując się do samokształcenia i testowania.

Słowa kluczowe: technologie informacyjne i komunikacyjne; usługi Google; technologie chmurowe; Internet; środowisko edukacyjne informacji; kształcenie przyszłych nauczycieli przedmiotów przyrodniczych 


\section{SUMMARY}

Modern computer achievements in scientific activity give access to common use of data from a great number of information repositories. The materials of the article are dedicated to defining the pedagogical possibilities of using Google services in training of future teachers of natural specialties. The article highlights the results of the assessment of the real state of educational activity of teachers and students with the use of modern information and communication technologies (hereinafter referred to as ICT). The article analyzes the learning objectives and widely used services, which enable active introduction of ICT in the process of conducting lectures and practical classes, while preparing for self-study and testing.

Keywords: information and communication technologies; Google services; cloud technologies; Internet; information educational environment; training of future teachers of natural specialties

\section{GOOGLE SERVICES}

Professional competence of future teachers undoubtedly depends on the skillful introspection of their educational level, allocation of inconsistencies and mistakes, acquisition of new knowledge, skills and abilities, adapted to modern new technologies that are constantly evolving and improving. Only conscious and critical attitude of students to their own learning outcomes, understanding the goals of their professional development, analytical approach to the process of professional development, clear design of their individual educational trajectory will increase the effectiveness of educational activity. Global public informatization, rapid growth of information sources, development of interactive technologies is the driving force for the reform of the traditional paradigm of education through the activation of educational and cognitive activity of future teachers, implementation of subject-subject relations between teachers and students, increasing the volume of self-study. Therefore, broad opportunities of ICT using becomes an integral part of the educational process.

Nowadays, a variety of advanced computer programs are used in the modern world, but not all of the higher educational establishments are provided with sufficient electronic means of education. That is why teachers need to be able to organize the educational process so that future specialists in their sphere could use the available devices with free access to Internet resources not only during the classroom activities, but also outside the school. This becomes possible with the use of Google services. The introduction of ICT in education, in particular the use of Google Services, improves training of future specialists, forms their skills of self-study, provides an opportunity to exchange information regardless of the student's location.

There has been conducted the analysis of recent research and publications. The issues of ICT implementation in the practice of higher education have been studied in the works of many authors. For example, the introduction of information and telecommunication technologies in the educational process and using them in 
the scientific research for students of pedagogical institutions were considered in the works of R. Hurevych (2004); problems of informatization of the educational process in schools and pedagogical universities have been studied by M. Zhaldak (2012).

With the purpose to improve the learning process, T. Arkhipova proposes to use such powerful technologies as cloud computing, which support traditional forms of learning, and are efficient, effective and flexible enough to meet the needs of students in obtaining new knowledge. The scientist notes that cloud computing is a dynamically scalable way to access external resources for computing in the form of a service provided via the Internet, and the user does not need special knowledge of the "cloud infrastructure" or skills to operate this "cloud technology" (Arkhipova 2013, pp. 99-108).

One of the directions of using information and communication technologies in higher education is learning via the Internet, which provides students with great opportunities for accessing educational information resources and cooperation. The studies of Yu. Tryus (2012) are aimed at the problems of using and creating web-based software that would enable students to learn and solve professionallyoriented problems at any time and from any place where there is access to the Internet. The works of O. Romanyshyna (2010) cover the issues of using the information learning system in the training of teachers. Foreign scientists L. Pope and J. Rochelle in their studies described the implementation of cloud services in the educational process (Google in Education, 2018).

However, certain aspects of using ICT remain unrevealed, in particular Google services as a means of enhancing educational and cognitive activity and development of creative thinking of future teachers of natural specialties.

The purpose of the article is to study the prospects of using Google services in the educational process while preparing future teachers of natural specialties. The use of Google applications allows one to modernize the educational and methodological support of subjects, so it is important to analyze the advantages and disadvantages of these information technologies.

The methodological basis of the study is presented by basic methods: a) theoretical: analysis of scientific, pedagogical and methodical literature on the selected problem; b) empirical: the study of students' activity in the process of practical training using ICT, observation, systematization and generalization of their own experience and the experience of teachers of the Kremenets Regional Humanitarian Pedagogical Academy named after Taras Shevchenko.

Google services are beginning to gain popularity in education when studying various subjects, including natural. Google environment contains enough tools for both individual and collective (group) activities. Google applications are focused on the interaction of people on the Internet, and as for the learning process, there are favorable opportunities for communication and cooperation in such a space. 
Peculiarities of introducing Google services into the professional work of experts were researched by foreign scientists J. Reich et al. (2008), V.A. Scott (2008), A.M. Bodzin et al. (2010) and others. O. Gribiuk (2018) states that "a cloud is a huge number of easy to use and accessible virtualized information resources (hardware, development platforms and/or services)".

For active use of Google services, teachers and students need to create their own profile on the website (https://www.google.com.ua), and they can successfully work with the most common applications:

1) Gmail is a Google mail for messaging, it has mobile access, virus and spam protection;

2) Google Drive is a cloud environment for storing files in one's own space and with Internet access to documents from the personal computer or mobile device;

3) Google Doc is a text document that can be worked with individually or collectively, sent by e-mail, published on the website or social networks;

4) YouTube is a service for viewing, downloading and using videos, allows to create one's own channels.

5) Google Calendar is a calendar that allows to schedule tasks, affairs, events; this applications allows one to set the time, set reminders or send notifications.

\section{USING GOOGLE SERVICES IN TRAINING OF FUTURE TEACHERS OF NATURAL SPECIALTIES}

The priority task of modern education is the formation of students' motivation to develop their educational strategy, which allows to set one's own goals, create an individual trajectory of their achievement, and choose one's own means of obtaining knowledge.

The use of Google services allows one to establish the best form of contact of a teacher with a student, at the same time, improving the quality of training of future teachers of natural specialties.

Using Google services by participants of the educational process has a number of advantages:

- quick and easy creation of one's own page;

- opening applications anywhere, without the need for a special purpose room;

- everything saved and placed in the service is protected from viruses or data deletion;

- establishment of differentiated openness and accessibility of information;

- $\quad$ free use of the service, a person needs to pay only for the Internet.

Working with Google services is easy and convenient, because they allow for a quick and free creation of a certain online resource with an individual design, selected from a sufficient number of templates. Everything can be done on one's 
own, without the help of IT specialists. But at the same time, the use of Google applications has a number of disadvantages:

- Google-services are available only when you are connected to the Internet, otherwise you cannot work with them;

- poorly configured protection allows attackers to use someone else's information without permission to access it;

- no application provides complete data privacy.

It is important for a modern teacher to be able to create an account, use Gmail, work with Google Drive, which allows to simplify and improve the preparation for classes, making various text documents, spreadsheets, drawings, presentations, various survey forms.

Active participation of students in the educational process using Google services increases their responsibility for the effectiveness of educational activity and leads to significant changes in the educational process. In modern conditions of overall informatization, the ICT is applied in teaching of most academic disciplines, thus, for future teachers of natural specialties mastering the skills of working with Google software products is very important.

In early 2018, we conducted a survey among students - biologists and ecologists of the I, II, III, IV, V and VI years of study of the Kremenets Regional Humanitarian Pedagogical Academy named after Taras Shevchenko (113 respondents). The following question was posed: What social networks and Google services do you use? The results presented in Fig. 1 show that the younger generation is $100 \%$ proficient in certain ICT skills. It can be stated that everyone has certain skills in using network information products, but each academic year, the number of students who use Google services and social networks increases significantly.

\section{Usage of Google services and social networks by students}

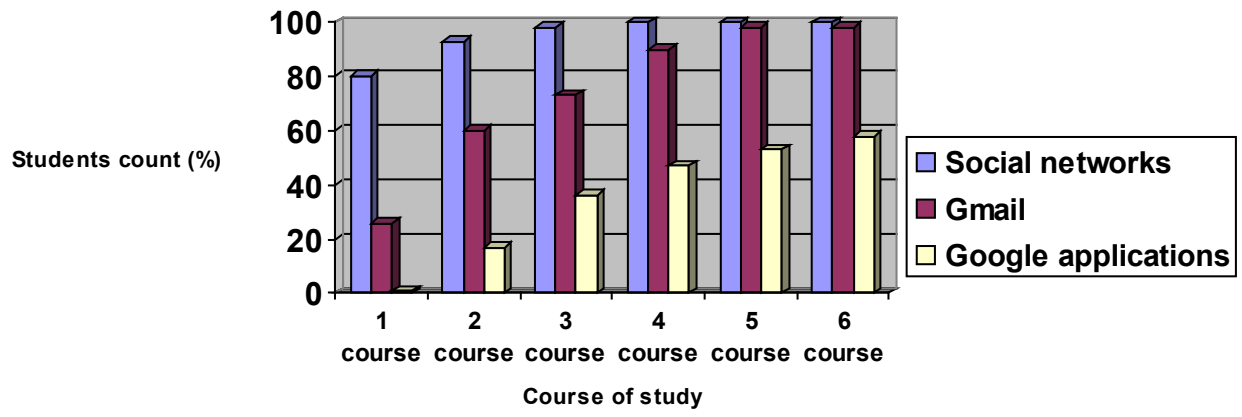

Fig. 1. Results of the study "Usage of Google services and social networks by students" Source: Authors' own study. 
Comparing the results of the research between the students of I, II, III and IV, $\mathrm{V}$ and VI years of study, we can see that the use of social networks from the first to the third year of study increases significantly, and in the fourth, fifth and sixth academic years all $100 \%$ of respondents communicate via social pages. Skills of using Gmail improve from the time of entering the higher educational establishment till the time of graduation (from $26 \%$ to $100 \%$ ). But the use of Google applications during the first year of study is known only to $4 \%$ of respondents, who only in the process of education learn to work with the applications, although not all of them: II year $-27 \%$, III year $-36 \%$, IV year $-47 \%$, V year $-53 \%$, VI year $58 \%$. That is, only $58 \%$ of future teachers of natural specialties, getting higher education, use Google services.

After conducting a survey among teachers of natural sciences, we learned that $25 \%$ of them do not use Google applications in their professional activity, $70 \%$ - use Gmail, 5\% - sometimes work with servers.

Thus, the analysis of the results of the two studies shows and encourages to more active use of ICT in the educational process, in particular network applications. It is necessary to increase the pace of development of information competence of young people through the implementation of a differentiated approach to teaching students, complementing the existing methodological support of academic disciplines by means of ICT. This will improve the motivation of future specialists to successful learning, development of personal qualities; additionally, it will contribute to creative activity and critical thinking.

Google applications, when used for educational purposes, can positively change the design of lessons, assignments, and student achievement assessment systems. The use of ICT by a teacher changes and modernizes lectures, which then contribute to stimulation of students' knowledge seeking for further self-study. According to Dybkova,

the task of a modern teacher is not so much to provide information, but to encourage students to study the topic independently, to form their own attitude to certain aspects of it, to search for sources of additional information, to encourage students for further self-study. In this case, independent work should become a component of the lecture, and the lecture - a component of self-study. In this sense, the educational activity of students during the lecture can be considered an independent work, which have to be monitored and evaluated by the teacher (Dybkova 2013, p. 174).

The use of Google services in educational activity provides an opportunity for active and creative interaction of the teacher with the students even at the lecture, where everyone not only writes a summary of the whole topic (write down only some information), but also takes an active part in discussions and case studies. And the usual lecture material posted in the online application can 
be viewed or printed at home. It is also advisable to propose to solve small-scale problems in applications to find a common solution. The teacher working online can observe the progress of each student. It is easier to control educational and cognitive activity and encourage self-study.

Also, all educational materials are available during the period of study of the subject to each user of a certain application, regardless of the presence in the classroom. The use of Google services for practical classes allows one to accomplish learning activities developed on the principles of interactivity, problem-solving, self-assessment, which has a significant impact on the development of professional and personal qualities of future specialists.

The Google Class service allows users to send messages to each other. This group contains e-mail addresses of participants who have the opportunity to communicate and interact together, for example, to perform practical work. Teachers can add or remove users, view messages in the discussion archive, and permit to create smaller groups. It is helpful to prepare projects: to choose topics, to divide students into groups, to distribute responsibilities. Having elaborated and prepared the project, and having filled the documents with content, the teacher gets access for verification. The teacher can comment on the work to allow children to edit the content. When evaluating a project, it is important to track the history of changes and adjustments.

At the same time, the acquisition of knowledge and skills is carried out through the active self-study of students; they demonstrate responsibility, and are characterized by initiative, self-esteem, or increased motivation to achieve their goals. The teacher, at the same time, has the opportunity to observe the work of each student, give advice, help, guide actions to obtain the desired result.

In contrast to the traditional form of practical training, the use of Google services contributes to the effective implementation of students' tasks for selfstudy, stimulates them to thorough and creative study of educational material. Test technologies implemented with the help of software products provide additional didactic opportunities for control measures. Openness and availability of results of educational activity for the individual users eliminate the level of subjectivity, implement continuous monitoring of current performance, promote motivation of students to educate themselves through a sense of justice of the marks received. Specialized search engines are used to look for the research information. For example, Google Academy allows to find scientific literature references, including reviewed articles, abstracts, reports, dissertations, or books.

The activity of students in the educational and cognitive process, understanding the importance of acquiring various professionally-oriented competencies, the choice of their educational goals lead to their formation as subjects of learning. 


\section{CONCLUSIONS}

The abilities to analyze, think critically, having a broad outlook and erudition, quick reaction and decision-making - these are the essential characteristics of the teacher, without which professional activity in the world of global and dynamic changes is impossible. It is the implementation of ICT into the educational process, especially the use of Google services, that is the right way to create and ensure continuous education. For modern students such training is easily accessible, because they can work and exchange information anywhere, at any time, using a variety of electronic devices, only when connected to the Internet.

Using the capabilities of Google applications in the learning process can enhance the activity of future specialists when preparing for practical classes, they also form a responsibility for the effectiveness of their activity. Google services can be of a special help for teachers, especially teachers of natural sciences, to expand their spectrum of work for laboratory and practical classes, seminars, online conferences, competitions, Olympiads.

The new requirements of the modern information society successfully change the paradigm of education from formal knowledge to practice-oriented. Preparation of future teachers of natural specialties for professional activity with the active use of modern ICT, in particular Google services, should be organized so as to provide digestion and consolidation of professional skills in short time, to transform knowledge-information into practical knowledge, followed by further implementation of their application in the school. Thus, having considered the real possibilities of using Google applications in the educational process, we saw how to effectively implement cooperation and interaction of teachers and students. Now there is a new direction in education - mobile learning, according to which it is necessary to possess not only skills to use a computer, but also mobile wireless devices and technologies. Considered Google services provide access to educational materials from any location, from any device, with the Internet connection only.

Therefore, the use of the Internet allows one to create an environment for independent, personalized, differentiated work, and, at the same time, productive interaction of all participants of the educational process. Further research should be aimed at the use of Google services in the educational process in the preparation of future teachers of natural specialties, which requires creation of appropriate methodological support of the selected disciplines. It is important to experimentally find out what competencies students acquire when using ICT, in particular Google applications. 


\section{REFERENCES}

Arkhipova, T. (2013). Vykorystannia „khmarnykh obchyslen” u vyshhii shkoli [The use of “cloud computing" in higher education]. Informacijni tekhnologii v osviti [Information Technologies in Education], 17.

Bodzin, A.M., Shiner Klein, B., Weaver, S. (2010). The Inclusion of Environmental Education in Science Teacher Education. USA: Springer.

Dybkova, L.M. (2013). Interaktyvni informacijni tekhnologii u navchalnomu procesi suchasnogo vyshu [Interactive information technologies in the educational process of modern universities]. Vyshha osvita Ukrainy: teoretychnyi ta naukovo-metodychnyi chasopys [Higher Education in Ukraine: Theoretical and Scientific Journal], 2.

Google v osviti [Google in Education]. Mode of access: https://blog.google (access: 17.04.2018).

Gribiuk, O.O. Perspektyvy vprovadzhennia khmarnykh texnologii v osviti [Prospects for the introduction of cloud technologies in education]. Mode of access: http://lib.iitta.gov.ua/1111.html (access: 17.04.2018).

Hurevych, R.S. (2004). Informaciino-telekomunikaciini tekhnologii u navchalnomu procesi ta naukovykh doslidzhenniakh [Information and Telecommunication Technologies in the Educational Process and Research]. Vinnycia: DOV „Vinnycia”.

Reich, J., Daccord, T., November, A. (2008). Best Ideas for Teaching with Technology: A Practical Guide for Teachers, by Teachers. New York: M.E. Sharpe.

Romanyshyna, O.Y. (2010). Pidgotovka vykladachiv do vykorystannia informacijnoii navchalnoii systemy Moodle u navchalnii diialnosti [Training of teachers to use the information learning Moodle system in educational activities]. In: Suchasni informaciini tekhnologii ta innovaciini metodyky navchannia $v$ pidgotovci fakhivciv: metodologiia, teoriia, dosvid, problem [Modern Information Technologies and Innovative Methods of Learning in Training of Specialists: Methodology, Theory, Experience, Problems]. Kyiv: KPI.

Scott, V.A. (2008). Google. Corporations That Changed the World. USA: Greenwood Publishing Group.

Tryus, Yu.V. (2012). Khmarni tekhnologii u profesiinii pidgotovci studentiv kompiuternykh specialnostej [Cloud Technologies in Professional Training of Students of Computer Specialties]. Kyiv: KPI.

Zhaldak, M.I. (2012). Problemy y informatyzacii uchebnogo processa v shkolakh y pedagogycheskykh unyversytetakh [Problems of Informatization of Educational Process in Schools and Pedagogical Universities]. Omsk: Izd-vo Om GPU. 